\title{
TOXICIDADE DE AGENTES CLAREADORES SOBRE STREPTOCOCCUS MUTANS
}

Luciane grochocki RESENDE, Edvaldo Antonio Ribeiro ROSA, Rosimeire Takaki ROSA, Antonio Adilson Soares de LIMA, Rodrigo Nunes RACHED

Embora os agentes de clareamento dental venham sendo utilizados extensivamente, efeitos biológicos adversos sobre estruturas do organismo e bactérias têm sido reportados. Objetivo deste estudo foi avaliar a toxicidade in vitro de agentes clareadores [peróxido de carbamida $16 \%(\mathrm{PC})$ e peróxido de hidrogênio 35\% (PH)] sobre Streptococcus mutans crescido em fase planctônica e biofilme em dois tempos de exposição continuada. Os resultados foram submetidos aos testes Kruskal-Wallis e $U$ de Mann-Whitney $(p<0,05)$. Os grupos $\mathrm{PH}, \mathrm{PC}$, e seus excipientes demonstraram efeito bactericida para as células em fase planctônicas, nos dois tempos. PC e PH apresentaram efeito bactericida em biofilme. Os tratamentos com excipientes apresentaram redução tempo-dependente na viabilidade de células crescidas em biofilme para todos os períodos de tempo. Os agentes clareadores e seus excipientes apresentaram toxicidade para Streptococcus mutans crescido em fase planctônica e em biofilme, nos dois tempos investigados. 